\section{Foliar Applied Abscisic Acid Increases 'Chardonnay' Grapevine Bud Freezing Tolerance during Autumn Cold Acclimation}

\author{
Imed E. Dami ${ }^{1,5}$, Shouxin $\mathrm{Li}^{1}$, Patricia A. Bowen ${ }^{2}$, \\ Carl P. Bogdanoff ${ }^{2}$, Krista C. Shellie ${ }^{3}$, and Jim Willwerth ${ }^{4}$
}

AdDitional InDEx wORDs. Vitis vinifera, hardiness, differential thermal analysis, cold injury

SUMMARY. Economic loss due to cold weather events is a major constraint to winegrape (Vitis vinifera) production and wine-related industries where extreme and/or fluctuating winter temperatures induce injury and require remedial retraining and replanting increases production costs and lowers yield and fruit quality. The purpose of this study was to determine whether a foliar application of abscisic acid (ABA) could increase the freezing tolerance (FT) of field-grown, 'Chardonnay' winegrape and whether its effectiveness can be influenced by the phenological timing of the application. Mature 'Chardonnay' grapevines were treated with a foliar application of $\mathrm{ABA}$ at a concentration of $500 \mathrm{mg} \cdot \mathrm{L}^{-1}$ at vine phenological stages corresponding to $50 \%$ véraison, postvéraison, and postharvest. Results from field trial sites located in four distinct winegrape production regions in the United States (Idaho and Ohio) and Canada (British Columbia and Ontario) showed that foliar application of ABA increased bud FT, primarily during autumn cold acclimation. Foliar ABA application had no consistent influence on bud FT in midwinter or during spring deacclimation, or on percent budburst in spring. Vine phenological stage at the time of $A B A$ foliar application influenced $A B A$ effectiveness, although results were inconsistent among locations. At most locations, applications made at véraison or postvéraison were more effective than applications made postharvest. No phytotoxic response or adverse changes in yield or berry composition were detected in response to ABA application. The consistent increase in bud FT during autumn cold acclimation observed at all trial locations in this study indicates that foliar ABA, applied at véraison or postvéraison, can reduce the risk of economic loss due to cold injury in production regions with frequent early autumn cold weather events.

A $n$ increased frequency of extreme and variable weather events poses a threat to winegrape production, where winter survival

This research was supported by funding from Agricultural Research Service Project 5358-21000-03400D entitled "Production Systems to Promote Yield and Quality of Grapes in the Pacific Northwest"; the British Columbia Wine Grape Council and Agriculture and Agri-Food Canada; the Ohio Grape Industries Program, and the Ohio State University Department of Horticulture and Crop Science. We thank Alan Muir, Monte Shields, and Cheryl Franklin-Miller for their technical expertise and Winemakers LLC and Meineke Vineyards for the use of their field resources and materials. Mention of a trademark, proprietary product, or vendor does not constitute a guarantee or warranty of the product by the U.S. Department of Agriculture and does not imply its approval to the exclusion of other products or vendors that also may be suitable.

${ }^{1}$ Department of Horticulture and Crop Science, Ohio Agricultural Research and Development Center, The Ohio State University, Wooster, OH 44691

${ }^{2}$ Pacific Agri-Food Research Centre, Agriculture and Agri-Food Canada, Summerland, British Columbia, VOH 1Z0, Canad

${ }^{3}$ Horticultural Crops Research Unit, USDA-ARS, Worksite Parma, Parma, ID 83660

${ }^{4}$ Cool Climate Oenology and Viticulture Institute, Brock University, St. Catharines, Ontario L2S 3Al, Canada

${ }^{5}$ Corresponding author. E-mail: dami.1@osu.edu. depends upon the ability of dormant tissue to withstand low temperature exposure and dynamically acclimate to winter temperature fluctuations. The number of grape and wine industries located in cold regions of the United States has increased by nearly 40\% between 2002 and 2005 (MKF Research, 2007) and these industries are important contributors to rural economies and associated agri-businesses and tourism. Since consumer preference dictates wine market trends, the winegrapes that currently dominate production acreage for premium wine are mostly European cultivars, which can be injured by exposure to cold temperature. These cultivars are especially susceptible to injury or death when exposed to freezing temperatures during autumn acclimation and spring deacclimation, and after a midwinter warming event (Zabadal et al., 2007). Cold weather events, such as late spring or early autumn frosts and extreme or fluctuating winter temperatures, have caused significant economic loss to grape production by decreasing yield and increasing cost of production due to required vine retraining and replacement (Zabadal et al., 2007). Winegrape production regions in northern United States and southern Canada have experienced substantial economic loss of production caused by cold weather events in 2003, 2004, 2005, 2009, 2012, and 2014 (Dami et al., 2012, 2014; Zabadal et al., 2007). The state of Ohio has experienced consecutive years of freezing-related loss of grape production for the last 5 years with the greatest loss occurring in 2014 (Dami et al., 2014; Dami and Lewis, 2014). Expansion of grape acreage, production sustainability, and the success of wine-related industries in production regions that experience winter cold are threatened by the frequent occurrence of cold weather events.

Active and passive protection methods have been developed to mitigate the threat of freezing stress on grapevines, with the purpose of either changing the meso-climate condition in the vineyard or improving the freeze tolerance of grapevines. Active protection methods include wind machines, heaters, and over-vine water application (Poling, 2008). Passive methods include site and cultivar selection (Zabadal et al., 2007) and the

\begin{tabular}{llll}
\hline $\begin{array}{l}\text { Units } \\
\text { To convert U.S. to SI, } \\
\text { multiply by }\end{array}$ & U.S. unit & SI unit & $\begin{array}{l}\text { To convert SI to U.S., } \\
\text { multiply by }\end{array}$ \\
\hline 10 & $\%$ & $\mathrm{~g} \cdot \mathrm{L}^{-1}$ & 0.1 \\
0.4047 & $\mathrm{acre}(\mathrm{s})$ & $\mathrm{ha}$ & 2.4711 \\
29.5735 & $\mathrm{fl} \mathrm{oz}$ & $\mathrm{mL}$ & 0.0338 \\
0.3048 & $\mathrm{ft}$ & $\mathrm{m}$ & 3.2808 \\
0.0929 & $\mathrm{ft}^{2}$ & $\mathrm{~m}^{2}$ & 10.7639 \\
3.7854 & $\mathrm{gal}$ & $\mathrm{L}$ & 0.2642 \\
0.4536 & $\mathrm{lb}$ & $\mathrm{kg}$ & 2.2046 \\
28.3495 & $\mathrm{Oz}$ & $\mathrm{g}$ & 0.0353 \\
1 & $\mathrm{ppm}$ & $\mathrm{mg} \cdot \mathrm{L}^{-1}$ & 1 \\
$\left({ }^{\circ} \mathrm{F}-32\right) \div 1.8$ & ${ }^{\circ} \mathrm{F}$ & ${ }^{\circ} \mathrm{C}$ & $\left({ }^{\circ} \mathrm{C} \times 1.8\right)+32$
\end{tabular}



(Dami and Beam, 2004). Among the chemical protectants, foliar applications of the plant growth regulator ABA have been found to increase FT in various crops including rye (Secale cereale) (Churchill et al., 1998), apple (Malus $\times$ domestica) (Guak and Fuchigami, 2001), and winegrapes (Zhang and Dami, 2012a, 2012b). Exogenous application of ABA to potted grapevines reduced growth and induced leaf abscission and periderm formation (Zhang et al., 2011), which are structural changes associated with induction of dormancy and cold acclimation.

'Chardonnay' winegrape is a moderately cold sensitive cultivar that is widely planted in production regions where winter weather events commonly cause cold injury. The purpose of this study was to investigate whether a foliar application of ABA could enhance the FT of 'Chardonnay' without adversely affecting yield or berry composition and to determine the most effective vine phenological stage for its application. We hypothesized that the effectiveness of foliar ABA to increase FT would be influenced by the phenological stage of the vine at the time of the foliar application and that exogenous ABA would not adversely influence yield or berry composition. We investigated these hypotheses by applying exogenous $\mathrm{ABA}$ to the canopy of field-grown 'Chardonnay' grapevines at three stages of berry development in field trial sites located in northern-latitude winegrape production regions in Canada and the United States and compared the yield, berry composition, and bud FT of vines with a foliar application of $\mathrm{ABA}$ to that of untreated control vines.

\section{Materials and methods}

Plant material, experimental DESIGN, AND TREATMENTS. The field trial sites in the United States were located in Nampa, Idaho (ID) and Geneva, Ohio (OH) and in Canada were located in Oliver, British Columbia (BC) and Vineland, Ontario $(\mathrm{ON})$. A description of field trial site locations and their associated winegrape production regions, elevation, soil type, vineyard planting density, training system, 'Chardonnay' clone, and rootstock is presented in Table 1 . Foliar ABA treatments were applied in application of chemical protectants

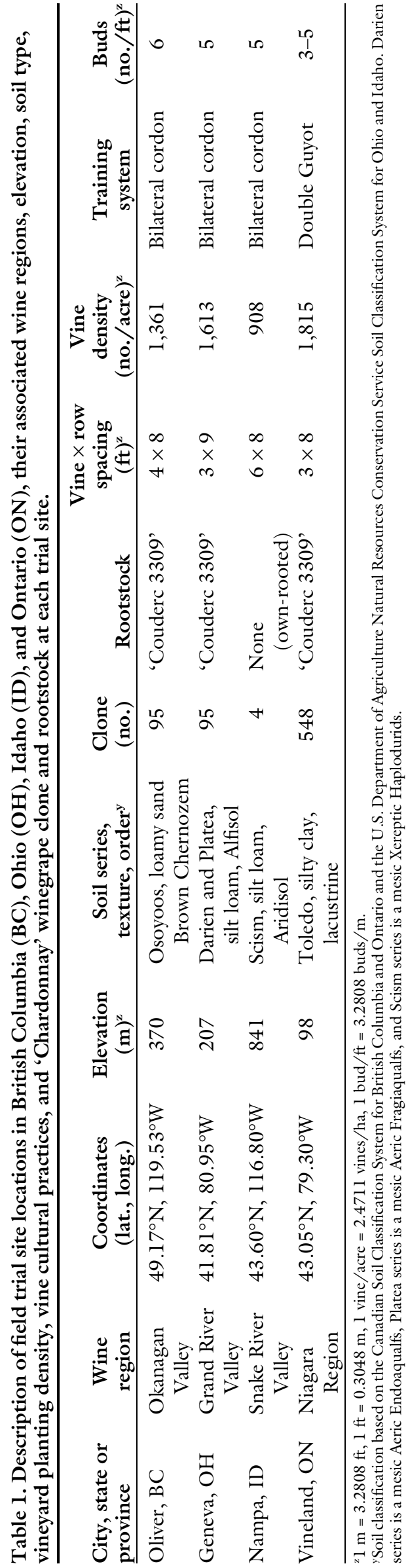


the first year of the study (2012-13) at all four field trial locations (Table 2). In the second year of the study (201314), foliar ABA applications were applied only at the $\mathrm{BC}$ and $\mathrm{OH}$ trial locations. The vines at all trial locations were spur-pruned in the spring to two buds per spur. ABA and control (no ABA) foliar spray solutions were prepared using deionized water and a spreader sticker surfactant (Latron B-1956 ${ }^{\circledR}$; Dow AgroSciences, Midland, $\mathrm{MI})$ at $0.05 \%$ a.i. $(\mathrm{v} / \mathrm{v})(\mathrm{BC}, \mathrm{ID}, \mathrm{OH})$ or $0.01 \%$ a.i. $(\mathrm{v} / \mathrm{v})(\mathrm{ON})$ (Table 2$)$. The ABA solutions contained 400 $\mathrm{mg} \cdot \mathrm{L}^{-1}$ (OH in year 1 of the study) or $500 \mathrm{mg} \cdot \mathrm{L}^{-1}$ (all other locations and years) $\mathrm{ABA}$ in the cis, trans configuration ( $\mathrm{S}-\mathrm{ABA}$ ), which is the natural form of ABA found in green plants. ABA solutions were prepared from soluble granules containing $20.0 \%$ (w/w) S-ABA (ProTone ${ }^{\circledR}$; Valent BioSciences, Libertyville, IL). The sprays were applied to both sides of the vine canopy (leaves and clusters) using a backpack sprayer that averaged a spray volume of $0.33-0.5 \mathrm{~L}$ per vine. The experimental design in each trial location was a randomized block with a factorial combination of foliar spray (control and $\mathrm{ABA}$ ) and application timing (véraison, postvéraison, or postharvest) as main effects randomized within replicate blocks (Table 2 ). The véraison application was made when $\approx 50 \%$ of clusters on a vine contained berries that had begun softening and had changed in color. Vines were harvested when fruit on untreated, control vines had attained a level of maturity, considered standard for local industry. The number of vines per treatment plot and number of replicate blocks per treatment varied by trial location; however, at all sites, treatment plots and replicate blocks were bordered by untreated vines. The postvéraison foliar application was not evaluated at the ID location.

BUd FREEZING TOLERANCE. The FT of buds was measured at each location in each year using differential thermal analysis (DTA) following the procedures of Mills et al. (2006). Freezing tolerance was expressed as the temperature at which lowtemperature exotherms (LTE) were detected for $50 \%$ of sampled buds $\left(\mathrm{LT}_{50}\right)$ as described by Mills et al. (2006) and Wolf and Pool (1987). Cane sampling for DTA was repeated at biweekly or monthly intervals from early autumn until the following spring. A representative, 1-year-old dormant (periderm formed) cane containing a minimum of 12 to 15 internodes was collected from each treatment-replicate. Buds on node positions three to seven were excised and mounted on thermoelectric modules (MELCOR, Trenton, NJ), which were placed inside a programmable temperature chamber $\left(\right.$ Tenney ${ }^{\circledR}$; Thermal Products Solutions, New Columbia, PA). The chamber temperature was lowered from above freezing to below the bud tissue lethal temperature at a rate of $4{ }^{\circ} \mathrm{C}$ per hour.

At the $\mathrm{OH}$ location, a visual assessment of cold injury was made in the second year of the study after a cold weather event that occurred on 6 Jan. 2014, when air temperature was $3{ }^{\circ} \mathrm{C}$ lower than the bud $\mathrm{LT}_{50}$ temperature of $-21^{\circ} \mathrm{C}$. Ten canes were removed from each plot unit and stored in the laboratory at room temperature for $24 \mathrm{~h}$. Buds at node positions one to ten were excised from each cane and categorized as dead or alive based upon the presence or absence of brown tissue.

SPRING BUDBURST. Budburst was evaluated each season following ABA treatment application at each trial location. In $\mathrm{BC}$ and $\mathrm{ON}$, budburst was quantified by calculating the percent of total buds per vine with visible green tissue. In $\mathrm{BC}$, the percent of buds with visible green tissue was assessed in year 1 on 26 Apr. 2013 and in year 2 on 7 May 2014. Two days after budburst (DAB) assessment in year 1 all shoots and primary buds were killed by a cold weather event (28 Apr. 2013). Regrowth and fruitfulness were evaluated $38 \mathrm{~d}$ after this cold event ( 5 June 2013) by counting the total number of shoots and clusters per vine and dividing the number of clusters by the number of shoots per vine. At the $\mathrm{ON}$ location, the percent of buds with visible green tissue was assessed in year 1 on 5 May 2013.

In $\mathrm{OH}$ and ID, budburst was quantified by recording the percent of buds per vine at or beyond a stage of the modified Eichhorn-Lorenz (E-L) grapevine growth stage scale (Coombe, 1995). In OH, the total number of buds per vine was recorded after pruning. Budburst was assessed on multiple dates in May 2013 over a span of 14-d as the percent of total buds per vine at $\mathrm{E}$-L stage five (rosette of leaf tips visible). Budburst was not evaluated in $\mathrm{OH}$ in study year 2 because of winter kill. At the ID location, budburst was assessed on multiple dates in Apr. 2013 over a span of $14 \mathrm{~d}$ as the percent of total buds per vine at or beyond E-L stage four [green tip (first leaf tissue visible)] on the first evaluation date and at or beyond E-L stage seven (first leaf separated from shoot tip) on the last evaluation date.

YIELD COMPONENTS, CROP LOAD, AND BERRY MATURITY. Yield, crop load, and berry composition were evaluated in years 1 and 2 of the study

Table 2. Field plot design and concentrations of abscisic acid (ABA) and surfactant in the foliar solutions that were applied to both sides of the vine canopy of 'Chardonnay' winegrape either at véraison $(\mathrm{V})$, postvéraison (PV), or postharvest ( $\mathrm{PH})$ at field trial sites in the United States and Canada.

\begin{tabular}{lcccccc}
\hline $\begin{array}{l}\text { Province } \\
\text { or state }\end{array}$ & $\begin{array}{c}\text { Application } \\
(\mathbf{y r})\end{array}$ & $\begin{array}{c}\mathrm{ABA} \\
\left(\mathbf{m g} \cdot \mathbf{L}^{-1}\right)^{\mathbf{z}}\end{array}$ & $\begin{array}{c}\text { Surfactant } \\
(\%)\end{array}$ & $\begin{array}{c}\text { Foliar application } \\
\text { timing }\end{array}$ & $\begin{array}{c}\text { Field } \\
\text { blocks (no.) }\end{array}$ & $\begin{array}{c}\text { Vines } \\
\left(\mathbf{n o} . / \text { plot }^{\mathbf{x}}\right.\end{array}$ \\
\hline British Columbiaw $^{\mathrm{y}}$ & 2012,2013 & 500 & 0.05 & $\mathrm{~V}, \mathrm{PV}, \mathrm{PH}$ & 6 & 2 \\
Ohio $^{\mathrm{z}}$ & 2012,2013 & 400,500 & 0.05 & $\mathrm{~V}, \mathrm{PV}, \mathrm{PH}$ & 4 & 14 \\
Idaho & 2012 & 500 & 0.05 & $\mathrm{~V}, \mathrm{PH}$ & 4 & 4 \\
Ontario & 2012 & 500 & 0.01 & $\mathrm{~V}, \mathrm{PV}, \mathrm{PH}$ & 3 & 6 \\
\hline
\end{tabular}

${ }^{\mathrm{z}} \mathrm{l} \mathrm{mg} \cdot \mathrm{L}^{-1}=\mathrm{l} \mathrm{ppm}$.

y $, \mathrm{PV}, \mathrm{PH}$ signify foliar application of ABA solutions at $50 \%$ véraison (berry softening and color change), postvéraison, and immediately postharvest, respectively.

'Plot size: $32 \mathrm{ft}^{2}$ (British Columbia), $351 \mathrm{ft}^{2}$ (Ohio), $144 \mathrm{ft}^{2}$ (Idaho), and $120 \mathrm{ft}^{2}$ (Ontario); $1 \mathrm{ft}^{2}=0.0929 \mathrm{~m}^{2}$.

"Yield and berry composition collected only at these locations. 
at only the $\mathrm{BC}$ and $\mathrm{OH}$ locations. Yield and cluster number per vine were recorded at harvest by weighing and counting the number of clusters removed per vine. Average cluster weight was calculated by dividing yield per vine by the number of clusters per vine. Average berry weight was determined from the weight of 20 to 100 berries per treatment replication that were collected randomly from each vine just before or at the time of harvest. Berry number per cluster was estimated as average cluster weight divided by average berry weight. Canopy size was estimated from the weight of pruned canes, determined by either summing the weight of the canes removed during each bud sampling and the remaining canes removed in the final March to early April pruning; or weighing all l-year-old canes/vine from vines left unpruned (not sampled for freezing tests) in each treatmentreplicate. Pruning weights were not determined in year 2 in $\mathrm{OH}$ due to inadvertent removal of vines by the cooperating grower after winter damage. The Ravaz index, also referred to as crop load, was calculated as the ratio of crop weight to pruning weight per vine (Ravaz, 1903).

Berry maturity indices [soluble solids (SS), $\mathrm{pH}$, and titratable acidity (TA)] were determined as described by Zhang et al. (2011). A 20- to 100berry sample per treatment replicate was collected just before or at harvest and crushed on the day of sampling using a mortar and pestle. The released juice was pressed through cheesecloth and used to measure SS with a digital refractometer (Pallette, Atago, Japan), pH with a $\mathrm{pH}$ electrode (London Scientific, London, ON, Canada), and TA by titrating $5 \mathrm{~mL}$ of juice with $0.1 \mathrm{~N}$ sodium hydroxide to a $\mathrm{pH}$ endpoint of 8.2 using an automatic titrator (Brinkmann Instruments, Mississauga, ON, Canada).

Statistical analysis. Data were tested for homogeneity of variance and normality (Levene's test and Shapiro-Wilk), transformed as needed (Box-Cox data transformation) and then analyzed by analysis of variance with $\mathrm{ABA}$, application timing, and their interaction as main effects. Bud FT data were analyzed by sampling date. Data were analyzed by phenological timing of application when the interaction between ABA and application timing was significant. Mean

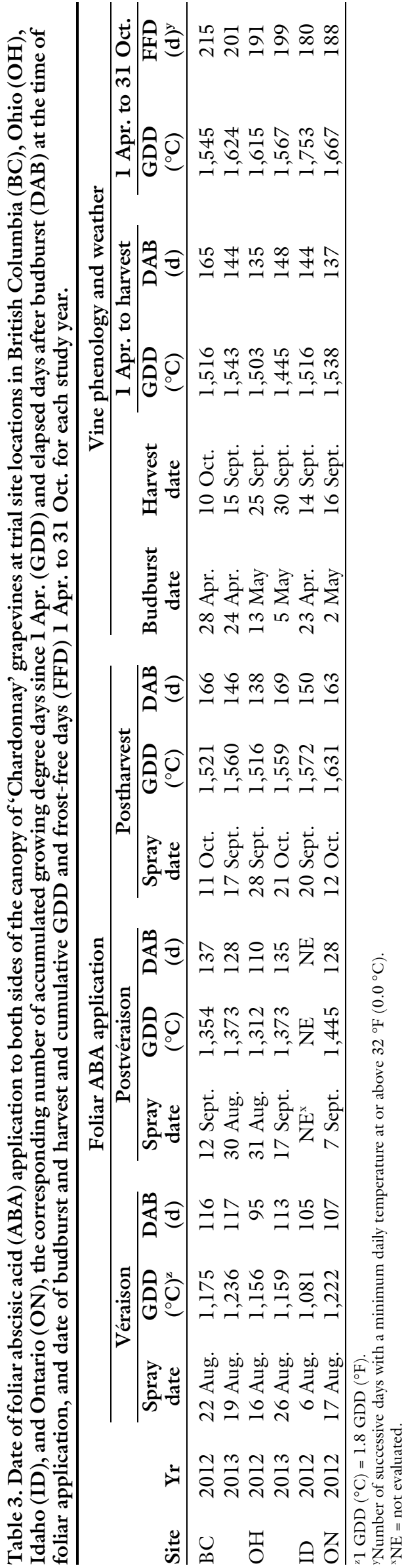



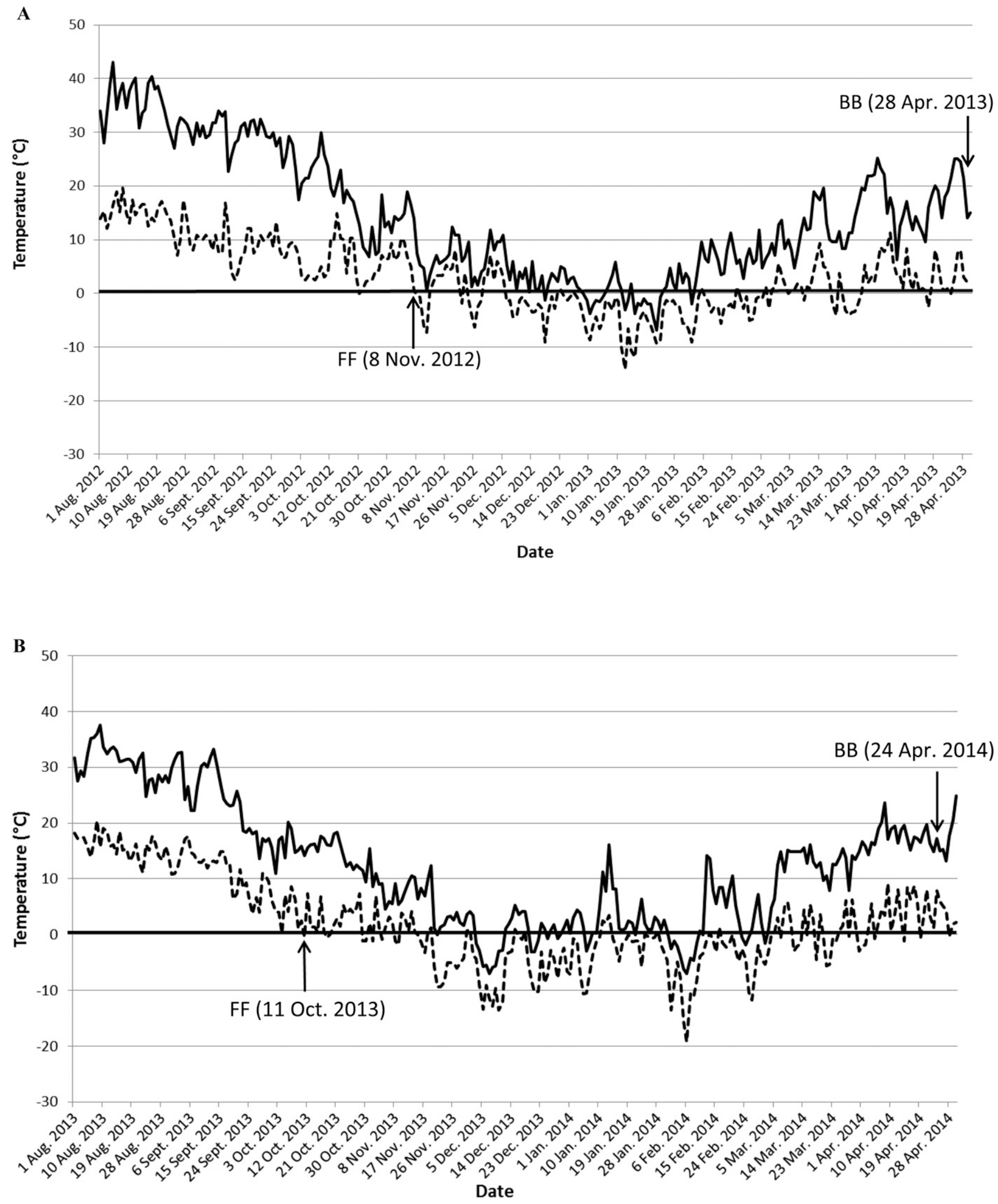

Fig. 1. Daily minimum (dashed line) and maximum (solid line) air temperature and dates of fall frost (FF) and budburst (BB) of 'Chardonnay' grapevines grown at field trial locations in (A) British Columbia 2012-13, (B) British Columbia 2013-14, (C) Idaho 2012-13, (D) Ohio 2012-13, (E) Ohio 2013-14, and (F) Ontario 2012-13. BB not shown in Fig. 1E because vines were killed during a cold event; $\left(1.8 \times{ }^{\circ} \mathrm{C}\right)+32={ }^{\circ} \mathrm{F}$. 
C

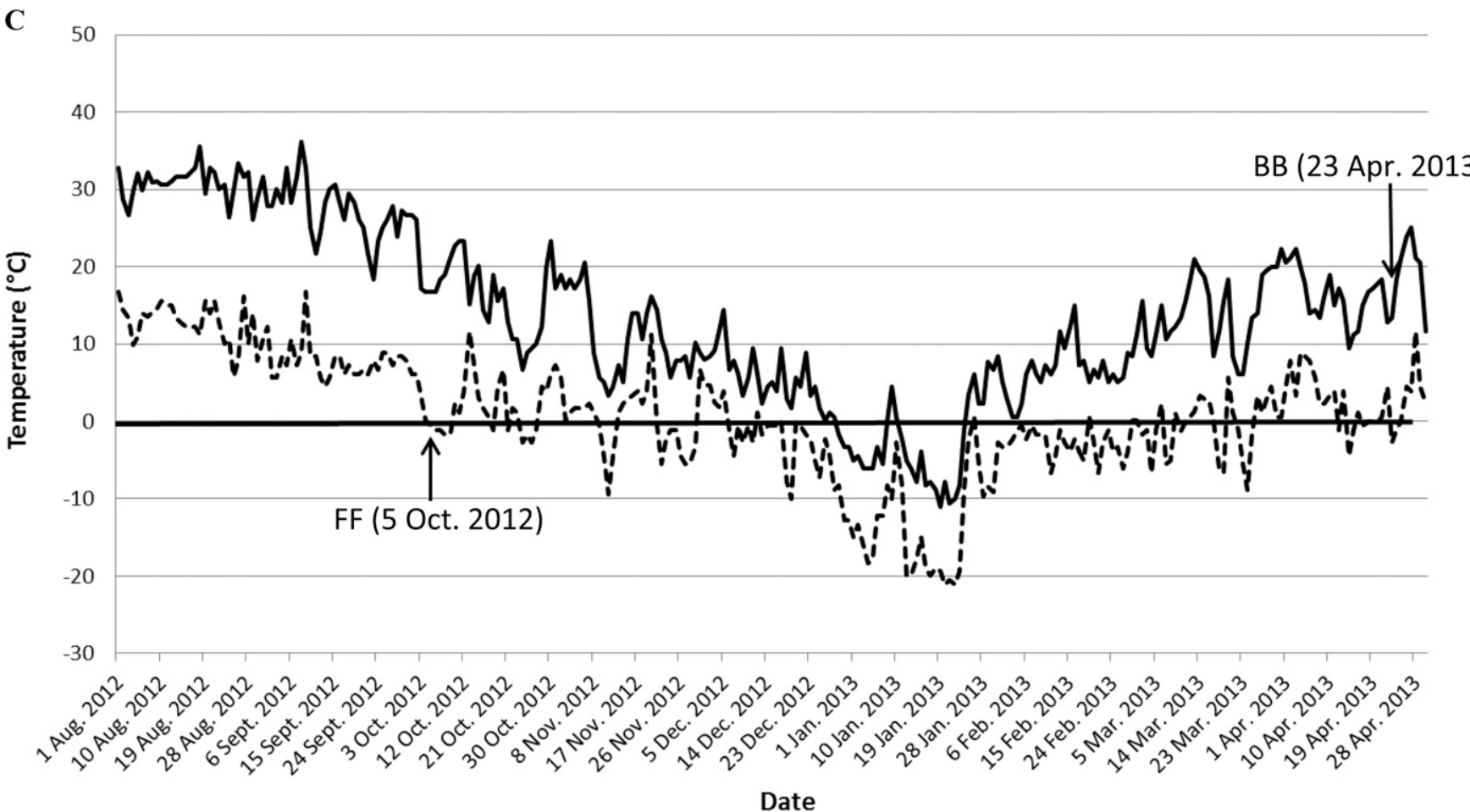

Date

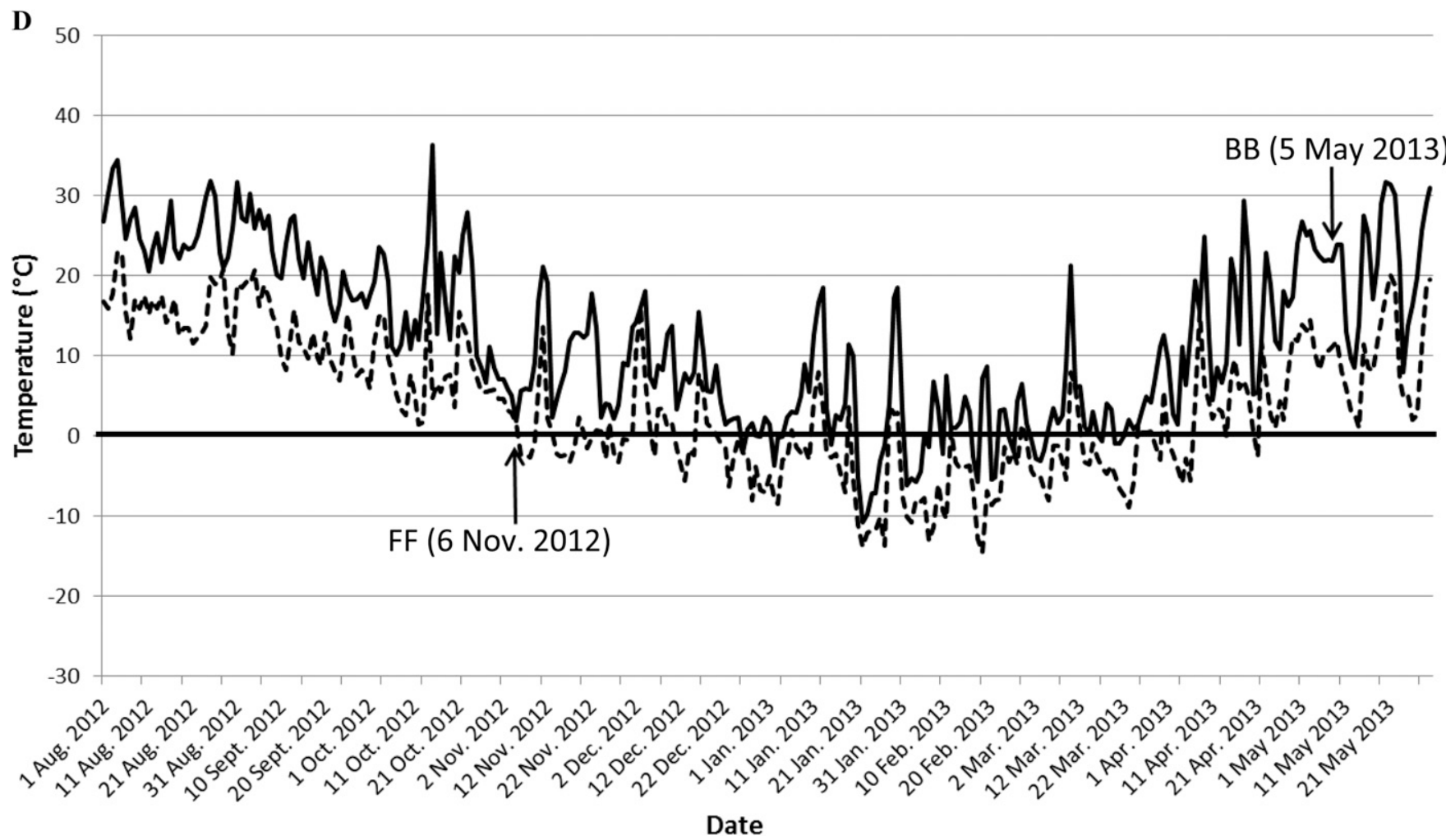

Fig. 1. Continued.

separation for significant $(P \leq 0.05)$ effects were detected using least significant difference $(\mathrm{OH})$ or TukeyKramer adjusted $t$ test (ID and ON). The same statistical software package was used to analyze data collected in $\mathrm{BC}, \mathrm{ID}$, and $\mathrm{OH}$ (SAS version 8.02 or 9.3; SAS Institute, Cary, NC) and a statistical add-on product (XLSTAT version 2013.3.04; Addinsoft, Paris,
France) was used to analyze data in ON. Seasonal FT data were graphed using a software graphics program (SigmaPlot 11.2; Systat Software, San Jose, CA). 

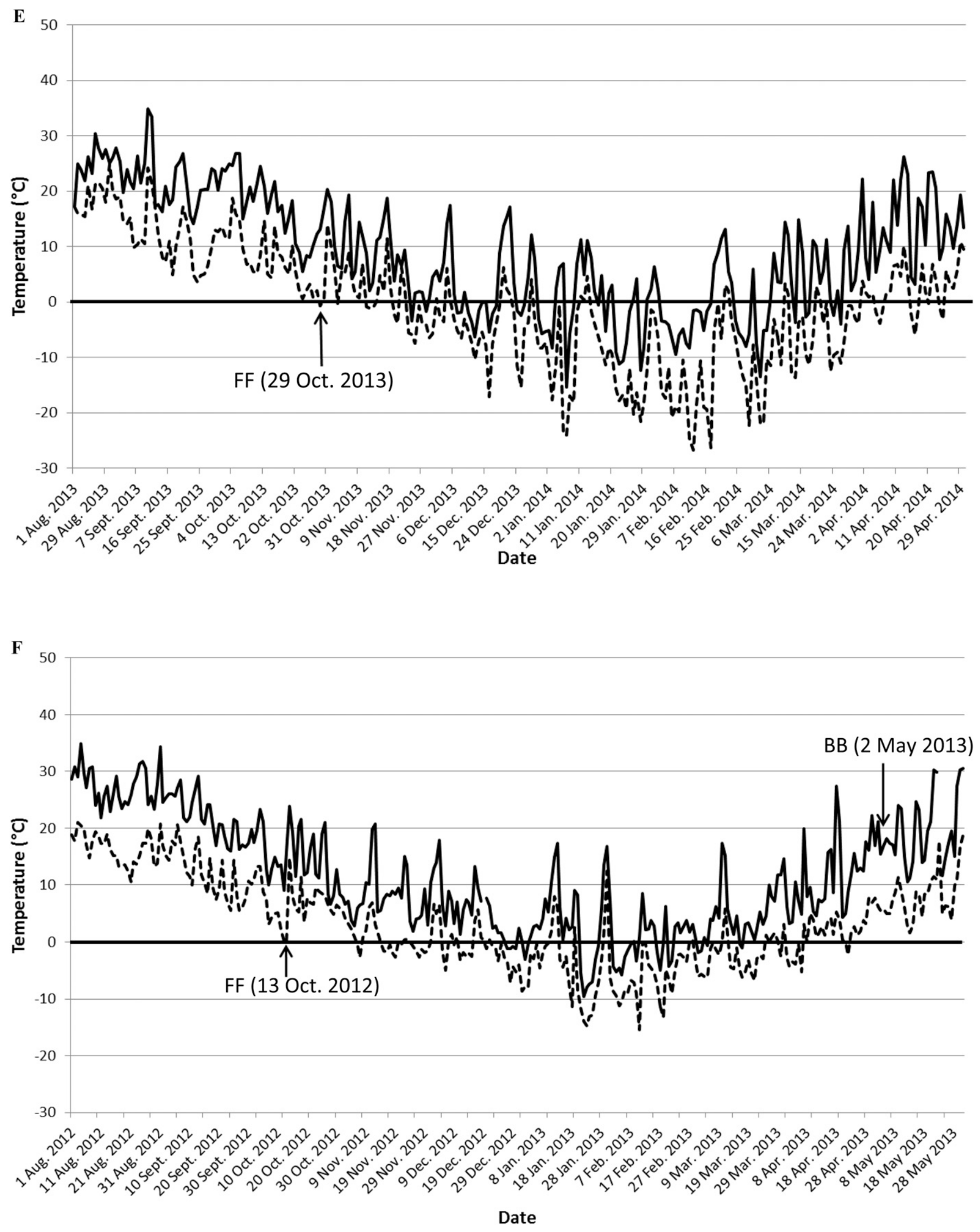

Fig. 1. Continued. 
Weather DATA. Daily minimum and maximum temperatures were either recorded in the vineyard using a temperature data logger $[\mathrm{OH}$ (Watchdog A-Series; Spectrum Technologies, Aurora, IL)] or obtained from a weather station located in proximity to the trial site [BC (British Columbia Climate Data, 2013), ID (U.S. Department of the Interior, 2013), ON (Weather Innovations, 2013)].

\section{Results}

Phenology and heat Unit ACCUMUlation. Spray application dates and their corresponding cumulative growing degree days (GDD) and $\mathrm{DAB}$ at the time of foliar application are summarized in Table 3 . Budburst at all locations occurred in late April to early May. Among the field trial locations and study years, the average interval between foliar treatment applications at véraison and postvéraison was $18 \mathrm{~d}$. The average number of DAB and cumulative GDD among locations and years at the time of the véraison $\mathrm{ABA}$ application were $( \pm$ SE) $109 \pm 8.3 \mathrm{~d}$, and $1172 \pm 55$ units in Celsius, respectively. The postvéraison foliar application was applied at an average of $127 \pm 11 \mathrm{DAB}$ when the average number of GDD was $1371 \pm 48$ units in Celsius. The average number of DAB and GDD among locations and years when grapes were harvested was $146 \pm 11 \mathrm{~d}$ and $1510 \pm 35$ units in Celsius, respectively. The time delay between the day of harvest and the day of postharvest ABA treatment application in year 1 of the study was $1,3,6$, and $21 \mathrm{~d}$ in $\mathrm{BC}, \mathrm{OH}, \mathrm{ID}$, and $\mathrm{ON}$, respectively. In year 2 of the study, the postharvest treatment was applied two and $21 \mathrm{~d}$ after harvest in $\mathrm{BC}$ and $\mathrm{OH}$, respectively. The average number of $\mathrm{DAB}$ and GDD among locations and years at the time of the postharvest application were $( \pm$ SE) $155 \pm 12 \mathrm{~d}$ and $1629 \pm 75$ units in Celsius, respectively.

Bud FreEzING TOLERANCE. The first-fall frost event in study year 1 (2012) occurred during the first and second week of October in ID and $\mathrm{ON}$, respectively, and during the first week of November in $\mathrm{BC}$ and $\mathrm{OH}$. In year 2 of the study (2013), the firstfall frost event occurred during the second and last week of October in $\mathrm{BC}$ and $\mathrm{OH}$, respectively (Fig. 1).
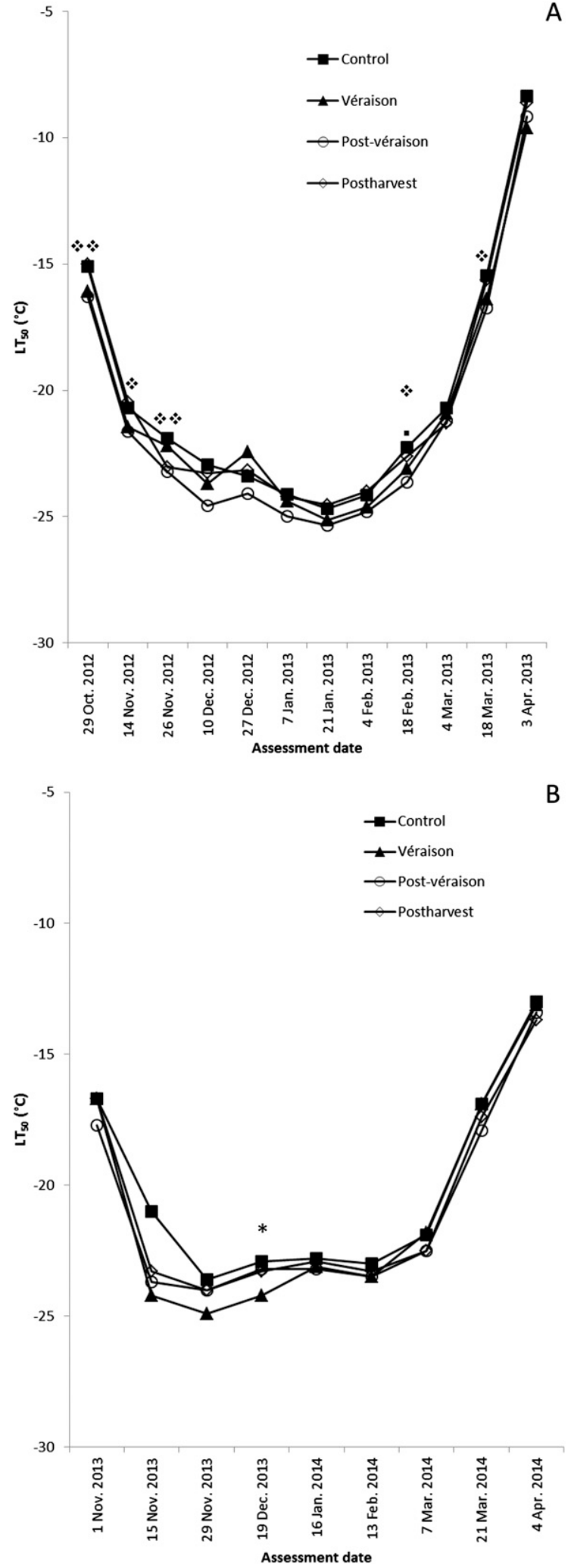

Fig. 2. Influence of foliar abscisic acid (ABA) applied at véraison (solid triangle), postvéraison (open circle), or postharvest (open diamond) on the lethal temperature for $50 \%$ of buds $\left(\mathrm{LT}_{50}\right)$ of 'Chardonnay' grapevine relative to buds from non-ABA control vines (solid square) as determined from low temperature exotherms using differential thermal analysis. Vines were grown in (A) British Colombia 2012-13 and (B) British Colombia 2013-14. Significant difference $(P \leq 0.05)$ from control for each application timing is indicated by * (véraison), (postvéraison), (postharvest), respectively. $*$ signifies $(P \leq 0.01) ;\left(1.8 \times{ }^{\circ} \mathrm{C}\right)+32={ }^{\circ} \mathrm{F}$. 

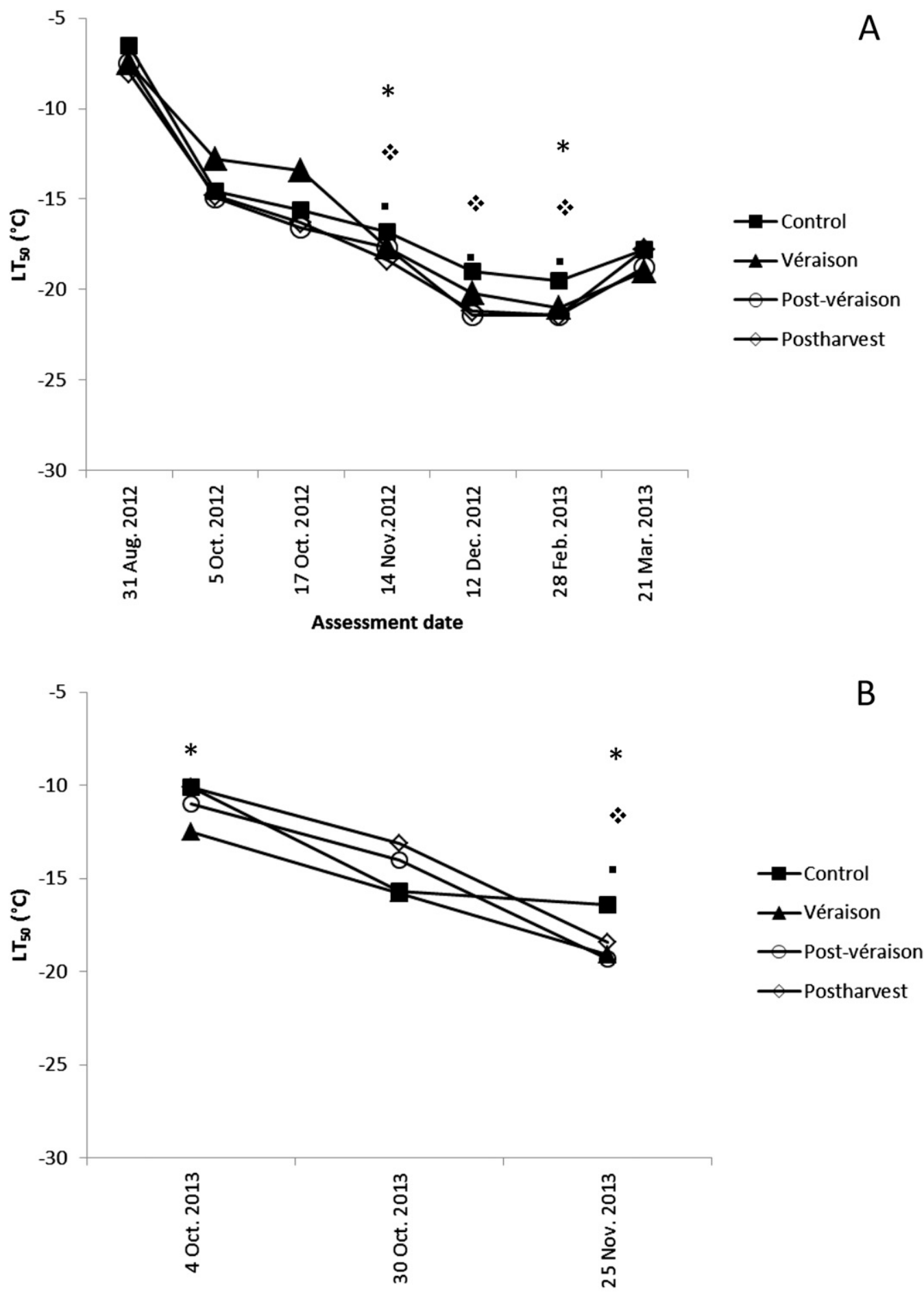

Assessment date

Fig. 3. Influence of foliar abscisic acid (ABA) applied at véraison (solid triangle), postvéraison (open circle), or postharvest (open diamond) on the lethal temperature for $50 \%$ of buds $\left(\mathrm{LT}_{50}\right)$ of 'Chardonnay' grapevine relative to buds from non- $\mathrm{ABA}$ control vines (solid square) as determined from low temperature exotherms using differential thermal analysis. Vines were grown in (A) Ohio 2012-13 and (B) Ohio 2013-14. Significant difference $(P \leq 0.05)$ from control for each application timing is indicated by * (véraison), (postvéraison), " (postharvest), respectively; $\left(1.8 \times{ }^{\circ} \mathrm{C}\right)+32={ }^{\circ} \mathrm{F}$.

The lowest temperature during the dormant season in year 1 occurred mid-January in ID $\left(-21.1^{\circ} \mathrm{C}\right), \mathrm{BC}$ $\left(-14.1^{\circ} \mathrm{C}\right)$, and $\mathrm{OH}\left(-14.6^{\circ} \mathrm{C}\right)$ and during the last week of January in ON $\left(-15.4^{\circ} \mathrm{C}\right)$. In year 2 of the study, the lowest temperature during the dormant season occurred in mid-February in $\mathrm{BC}\left(-19.3^{\circ} \mathrm{C}\right)$ and $\mathrm{OH}\left(-26.8^{\circ} \mathrm{C}\right)$. In all locations except $\mathrm{OH}$, minimum air temperatures throughout dormancy were higher than midwinter
$\mathrm{LT}_{50}$ temperatures. In the first year of the study, foliar ABA increased bud FT in October in BC, ID, and ON. In $\mathrm{OH}$, exogenous $\mathrm{ABA}$ did not significantly increase bud FT until the 14 Nov. sampling (Figs. 2A, 3A, 4, 5). In 


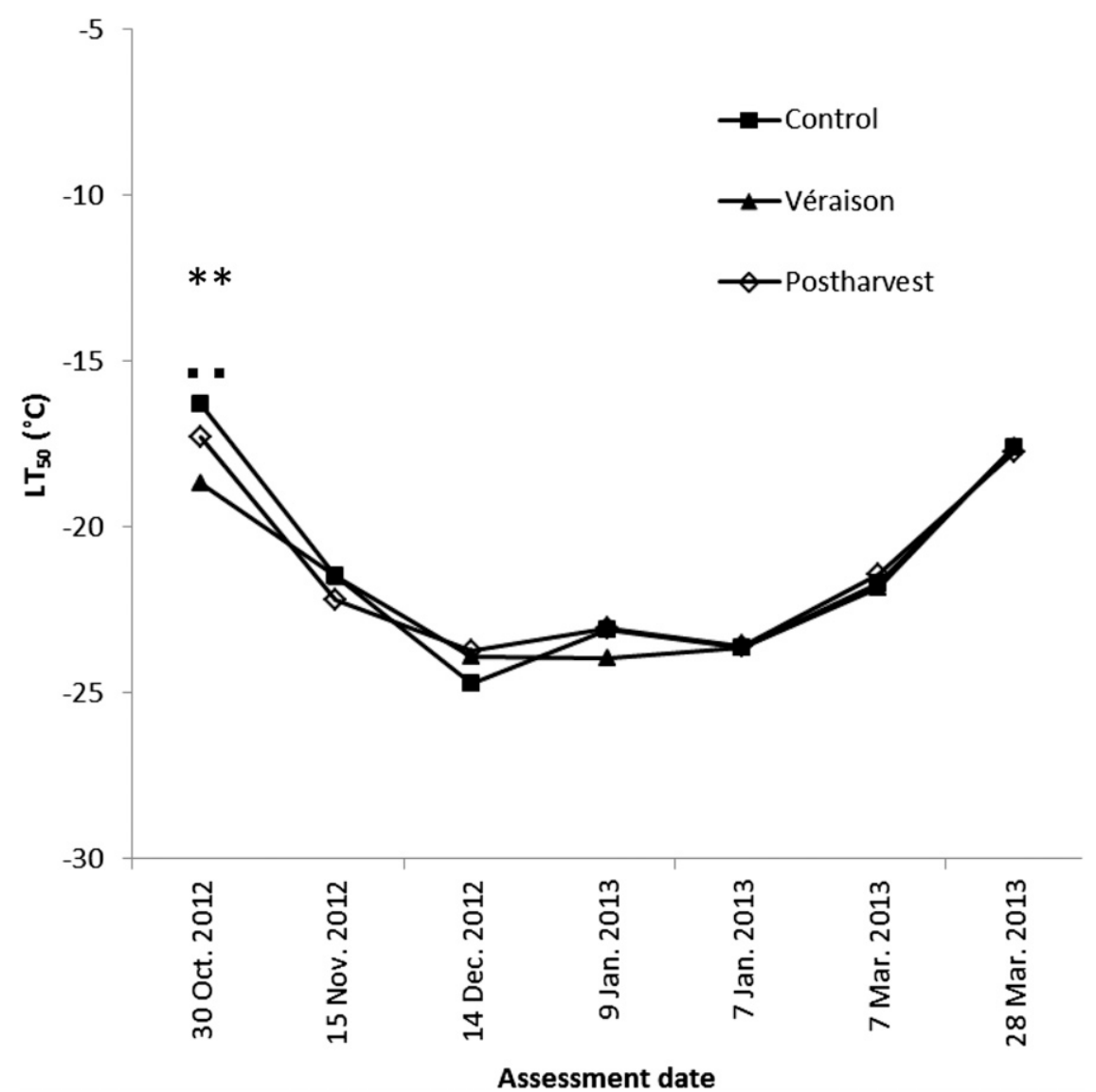

Fig. 4. Influence of foliar abscisic acid ( $A B A)$ applied at véraison (solid triangle) or postharvest (open diamond) on the lethal temperature for $50 \%$ of buds $\left(\mathrm{LT}_{50}\right)$ of 'Chardonnay' grapevine relative to buds from non-ABA control vines (solid square) as determined from low temperature exotherms using differential thermal analysis. Vines were grown in Idaho in 2012-13. Significant difference $(P \leq 0.01)$ from control is indicated by * * (véraison), $\mathrm{m}$ (postharvest), respectively; $\left(1.8 \times{ }^{\circ} \mathrm{C}\right)+$ $32={ }^{\circ} \mathrm{F}$.

the second year of the study, foliar ABA increased bud FT in early October in $\mathrm{OH}$; however, a significant increase was not detected in $\mathrm{BC}$ until mid-December. Foliar ABA increased bud FT less consistently during midwinter (December through February) and deacclimation (March through April) than it did in the month of October.

The phenological timing of $\mathrm{ABA}$ application significantly influenced bud FT on some sampling dates at each of the study locations (Figs. $2-5)$. With the exception of the ON location, postharvest applications of ABA were less effective at increasing bud FT than applications made at postvéraison or at véraison. When ABA was applied postvéraison in year 1 , bud FT increased relative to the control at all locations on each sampling date for which a significant ABA effect was detected. Véraison
FT was increased only during autumn cold acclimation. ABA application had no detectable effect on FT in midwinter (27 Dec. to 4 Feb.) when average $\mathrm{LT}_{50}$ was $-24.2^{\circ} \mathrm{C}$. In year 2 of the study (Fig. 2B), bud FT was increased by $1.2^{\circ} \mathrm{C}$ in mid-December on vines that received a véraison foliar application of ABA.

At the $\mathrm{OH}$ location, $\mathrm{ABA}$, applied at véraison, increased bud FT by $\approx 2.4{ }^{\circ} \mathrm{C}$ during autumn cold acclimation only in the second year of the study on 4 Oct. and 25 Nov. (Fig. 3B). All ABA applications increased bud FT by 1.1 to $1.9{ }^{\circ} \mathrm{C}$ during midwinter in the first year of the study (Fig. 3A), but had no detectable effect on FT during deacclimation. The visual assessment in the second year of the study of bud viability after the $-24{ }^{\circ} \mathrm{C}$ cold weather event was similar for buds from ABA-treated and nontreated control vines. All primary, secondary, and tertiary buds and phloem tissue sustained $100 \%$ damage (data not shown).

At the ID location, the buds of ABA-treated vines were $3.3{ }^{\circ} \mathrm{C}$ more cold hardy during autumn cold acclimation (30 Oct.) than buds from control vines (Fig. 4). Differences in FT were not significant on any other sampling date. At the ON location, bud $\mathrm{LT}_{50}$ was affected by ABA treatments during autumn cold acclimation (19 Oct.), where bud FT was increased in response to $\mathrm{ABA}$ applied at postvéraison or postharvest compared with $A B A$ applied at véraison or the control treatment (Fig. 5). No treatment differences in bud FT were detected during midwinter (December, January, and February) or during spring deacclimation.

SPRING BUDbURST. The percent budburst of ABA-treated vines was not statistically different from control vines at any location (Table 4). In BC, in study year l (2012-13), percent budburst was assessed two days before a cold weather event on 28 Apr. that killed all primary buds and shoots. The number of shoots per vine that developed from secondary or tertiary buds averaged 36 per vine and was unaffected by the ABA treatments. However, the fruitfulness of these shoots was increased by ABA when it was applied postvéraison or postharvest in the previous year. Vines that received a foliar application of $\mathrm{ABA}$ postvéraison or postharvest 


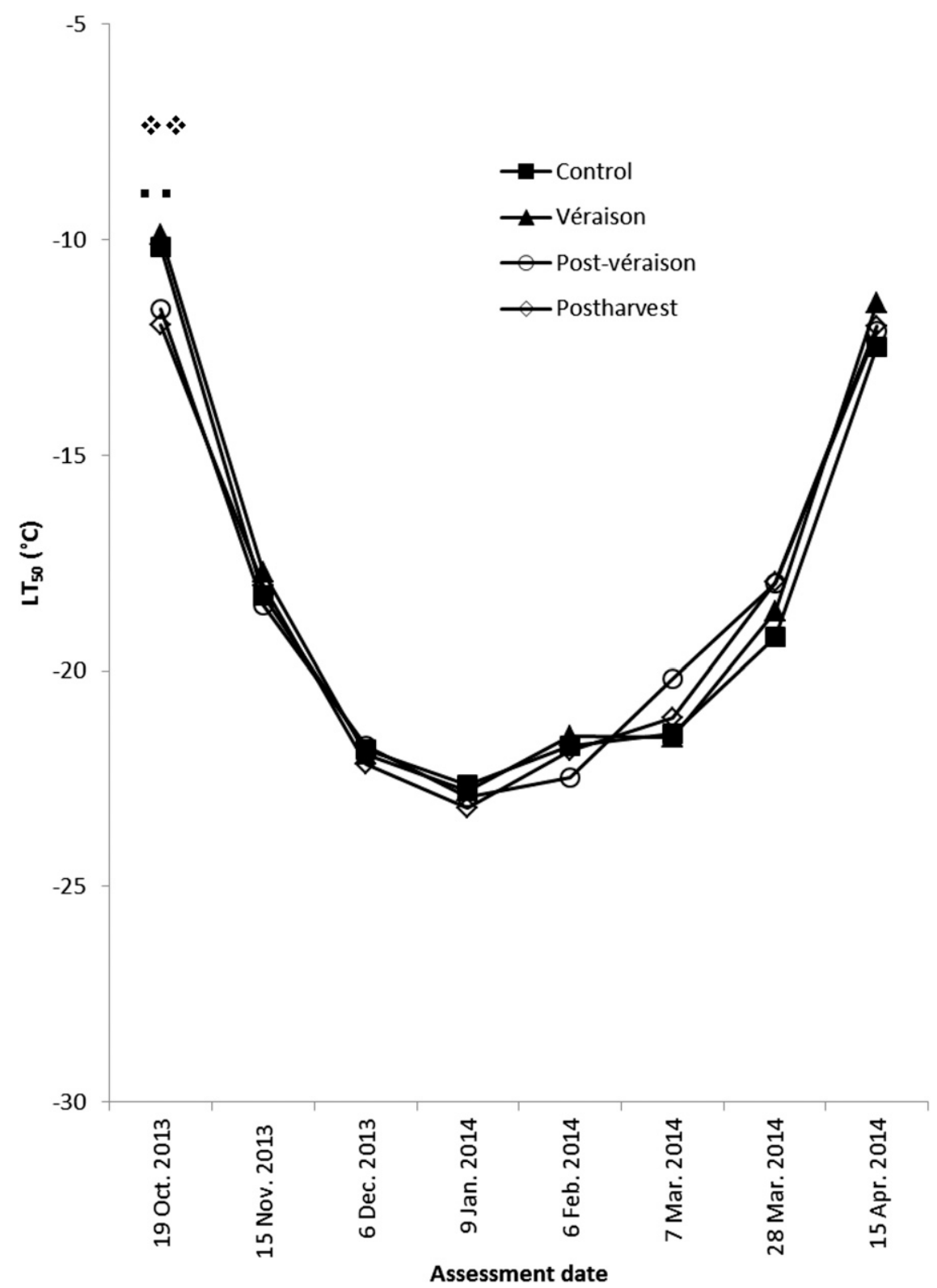

Fig. 5. Influence of foliar abscisic acid (ABA) applied at véraison (solid triangle), postvéraison (open circle), or postharvest (open diamond) on the lethal temperature for $50 \%$ of buds $\left(\mathrm{LT}_{50}\right)$ of 'Chardonnay' grapevine relative to buds from non-ABA control vines (solid square) as determined from low temperature exotherms using differential thermal analysis. Vines were grown in Ontario in 2012-13. Significant difference $(P \leq 0.01)$ from control is indicated by (veraison), $\square$ (postharvest), respectively; $\left(1.8 \times{ }^{\circ} \mathrm{C}\right)+32={ }^{\circ} \mathrm{F}$.

had $\approx 35 \%$ and $29 \%$ more clusters per shoot, respectively, than control vines. Abscisic acid applied at véraison had no effect on shoot fruitfulness.

Phytotoxicity and vegetative GROWTH. No symptoms of phytotoxicity were observed on leaves after ABA treatment application at any location in any study year. There were also no ABA treatment effects on vine pruning weight, which averaged 1.08 and $0.31 \mathrm{~kg} /$ vine, respectively, in $\mathrm{BC}$ and $\mathrm{OH}$ (data not shown). the second year of study. At the BC location, mean values for yield components and berry maturity indices in year l of the study were; $3.46 \mathrm{~kg} /$ vine yield, 33 clusters/vine, $104 \mathrm{~g}$ cluster weight, 69 berries/cluster, $1.52 \mathrm{~g}$ berry weight, $21.5 \%$ SS, pH 3.27, and $9.9 \mathrm{~g} \cdot \mathrm{L}^{-1}$ TA. Mean values for yield components and berry maturity indices at the $\mathrm{BC}$ location in the second year of the study were the following: $4.75 \mathrm{~kg} /$ vine yield, 35 clusters/vine, $139 \mathrm{~g}$ cluster weight, 104 berries/cluster, 1.33 g berry weight, $23.7 \%$ SS, $\mathrm{pH} 3.43$, and 5.5 $\mathrm{g} \cdot \mathrm{L}^{-1} \mathrm{TA}$. The Ravaz index at the $\mathrm{BC}$ location had a mean value of 3.2 and 6.0 in the first and second year of study, respectively. At the $\mathrm{OH}$ location in year 2 of the study, the mean values for yield components and berry maturity indices were; $3.74 \mathrm{~kg}$ /vine yield, 38 clusters/vine, 99.8 g cluster weight, 65 berries/cluster, $1.54 \mathrm{~g}$ berry weight, $17.5 \% \mathrm{SS}, \mathrm{pH} 3.51$, and $8.6 \mathrm{~g} \cdot \mathrm{L}^{-1} \mathrm{TA}$.

\section{Discussion}

Our findings that exogenous ABA increased the bud FT of the winegrape cultivar 'Chardonnay' supports the findings of other researchers for several other herbaceous and woody plants including arabidopsis [Arabidopsis thaliana (Mantyla et al., 1995)], silver birch [Betula pendula (Li et al., 2003)], barley [Hordeum vulgare (Bravo et al., 1998)], rye [Secale cereale (Churchill et al., 1998], wheat [Triticum aestivum (Dallaire et al., 1994)], chickpea [Cicer arietinum (Kumar et al., 2008)], potato [Solanum tuberosum (MoraHerrera and Lopez-Delgado, 2007)], sugar maple [Acer saccharum (Bertrand et al., 1997)], apple (Guak and Fuchigami, 2001), 'Cabernet franc' winegrape (Zhang and Dami, 2012a), and 'Chambourcin' interspecific winegrape [Vitis sp. (Zhang and Dami, 2012b)]. The influence we observed of phenological growth stage at the time of application on ABA effectiveness supports the findings of others in arabidopsis and grapevines. Exogenous ABA application was found to accelerate senescence and cell death in mature but not immature leaves of arabidopsis (Lee et al., 2011). Exogenous ABA application has been found to be most effective in inducing endodormancy (cessation of shoot growth, periderm development, leaf senescence, 
Table 4. Influence of abscisic acid (ABA) on timing of budburst the spring following foliar applications to the canopy of 'Chardonnay' grapevines at véraison ( $50 \%$ berry softening and color change), postvéraison or postharvest in 2012 and 2013 in field trials located in British Columbia (BC), Ohio (OH), Idaho (ID), and Ontario (ON). At each foliar ABA application, control vines received a foliar application of surfactant solution without $\mathrm{ABA}$.

\begin{tabular}{|c|c|c|c|c|c|c|c|c|c|c|}
\hline \multirow{3}{*}{ Timing } & \multicolumn{8}{|c|}{ Spring 2013} & \multirow{2}{*}{\multicolumn{2}{|c|}{$\begin{array}{c}\text { Spring } 2014 \\
\text { Budburst (\%) }\end{array}$}} \\
\hline & \multirow{2}{*}{ Budburst (\%) } & \multirow{2}{*}{$\begin{array}{c}\begin{array}{c}\text { Shoots } \\
\text { (no./vine) }\end{array} \\
\text { BC }\end{array}$} & \multirow{2}{*}{$\begin{array}{c}\text { Clusters } \\
\text { (no./shoot) }\end{array}$} & \multicolumn{5}{|c|}{ Budburst (\%) } & & \\
\hline & & & & \multicolumn{2}{|c|}{$\mathrm{OH}$} & \multicolumn{2}{|c|}{ ID } & $\frac{\mathrm{ON}}{5 \mathrm{May}}$ & $\frac{\text { BC }}{7 \text { May }}$ & $\begin{array}{l}\mathrm{OH} \\
\mathrm{NE}^{\mathrm{x}} \\
\end{array}$ \\
\hline \multicolumn{11}{|l|}{ Véraison } \\
\hline $\mathrm{ABA}$ & 4 & 37 & 0.65 & 23 & 87 & 58 & 40 & 25 & 62 & $\mathrm{NE}$ \\
\hline \multicolumn{11}{|l|}{ Postvéraison } \\
\hline $\mathrm{ABA}$ & 7 & 34 & 0.81 & 13 & 91 & $\mathrm{NE}$ & $\mathrm{NE}$ & 22 & 73 & $\mathrm{NE}$ \\
\hline Control & 5 & 39 & 0.60 & 28 & 88 & $\mathrm{NE}$ & $\mathrm{NE}$ & 27 & 71 & $\mathrm{NE}$ \\
\hline Significance & NS & NS & * & NS & NS & $\mathrm{NE}$ & $\mathrm{NE}$ & NS & NS & $\mathrm{NE}$ \\
\hline Significance & NS & NS & * & NS & NS & NS & NS & NS & NS & $\mathrm{NE}$ \\
\hline
\end{tabular}

and abscission) in grapevines when leaves were 120- to 140-d old (Zhang et al., 2011; Zhang and Dami, 2012a).

The response of bud FT to ABA treatments in this study varied among field trial locations and between years. Some of this variability can be attributed to locational and seasonal differences in weather conditions (temperature, humidity, rain, and solar radiation). Site conditions and management practices could also have contributed to variability among locations. When ABA was applied at the same vine phenological stage (i.e., véraison, postvéraison, and postharvest), the number of $\mathrm{DAB}$ at the time of $\mathrm{ABA}$ treatment application varied among locations at each phenological stage (Table 3 ). The DAB ranged between 95 to 117 d (23\% variability) at véraison; from 110 to $137 \mathrm{~d}(25 \%$ variability) at postvéraison; and from 138 to 169 d $(22 \%$ variability) at postharvest. Some of the variability in bud FT in response to the timing of the $\mathrm{ABA}$ treatment applications may have been due to differences among locations and years in the number of lapsed $\mathrm{DAB}$ at the time of foliar ABA application. Our findings that ABA treatments applied postharvest were generally less effective in increasing bud FT during autumn acclimation than ABA treatments applied at véraison and postvéraison coincide with a number of $\mathrm{DAB}$ at postharvest that was >138 d and between 95 to $137 \mathrm{~d}$ when ABA was applied at véraison or postvéraison. Zhang et al. (2011) and Zhang and Dami (2012a) found that exogenous ABA induced endodormancy most effectively when leaves were 110- to 137-d old. Induction of endodormancy has been associated with increased bud FT (Zhang and Dami, 2011). The leaf ages ( 95 to $137 \mathrm{~d}$ ) responsive to exogenous ABA for increasing bud FT during autumn acclimation in this study were similar to the leaf ages found by Zhang and Dami (2012a) to be most sensitive to induction of endodormancy. These findings suggest that leaf age influences the sensitivity of response to exogenous $\mathrm{ABA}$ for increasing bud FT during autumn acclimation, and that leaf age may be a more accurate indicator for timing ABA treatment applications than vine phenological stage.

The lack of phytotoxic response or detectable influence of the ABA treatment on yield components or berry maturity observed in this study are in agreement with the findings of others for winegrapes (Zhang and
Dami, 2012a, 2012b) and table grapes [ $V$. vinifera (Lurie et al., 2009; Peppi et al., 2007)]. Our results support that foliar ABA application has no adverse effects on yield or berry maturity and that 'Chardonnay' tolerates foliar ABA concentrations of 400 and $500 \mathrm{mg} \cdot \mathrm{L}^{-1}$ in solution with a spreader sticker surfactant.

Foliar ABA application did not affect the percent of budburst in the spring following treatment at any field trial locations. These results are similar to the findings of Hellman et al. (2006) who reported that exogenous ABA application delayed budburst in potted but not field-grown grapevines. The serendipitous observation at the $\mathrm{BC}$ location in year 1 of the study, that ABA application postvéraison or postharvest substantially increased the number of clusters per shoot in cold-injured vines, suggests that ABA may enhance the survival of fruitful secondary buds or cluster primordia development in nonprimary (secondary or tertiary) buds. The lack of effectiveness on fruitfulness when the foliar ABA was applied at véraison suggests that secondary bud survival or primordia development in nonprimary buds may not be receptive to $\mathrm{ABA}$ until late in the growing season. The observed increase 
in fruitfulness of nonprimary buds on cold-injured vines that had received a foliar application of ABA may indicate an additional mechanism by which exogenous $\mathrm{ABA}$ could reduce yield loss from cold injury and warrants further investigation.

In conclusion, foliar ABA application at the concentration of $500 \mathrm{mg} \cdot \mathrm{L}^{-1}$ effectively increased the bud FT of 'Chardonnay' during autumn acclimation without adversely affecting growth, yield, or berry maturity. The findings from this study are beneficial to grape growers in production regions with cold winters where foliar application of ABA may provide an additional tool for mitigating cold injury in 'Chardonnay'.

\section{Literature cited}

Bertrand, A., G. Robitaille, Y. Castonguay, P. Nadeau, and R. Boutin. 1997. Changes in ABA and gene expression in coldacclimated sugar maple. Tree Physiol. $17: 31-37$.

Bravo, L.A., G.E. Zuniga, M. Alberdi, and L.J. Corcuera. 1998. The role of ABA in freezing tolerance and cold acclimation in barley. Physiol. Plant. 103:1723 .

British Columbia Climate Data. 2013. Osoyoos, BC. 28 May 2014. <http:// weather.gc.ca/city/pages/bc-69_metric_e. html>.

Churchill, G.C., M.J.T. Reaney, S.R. Abrams, and L.V. Gusta. 1998. Effects of abscisic acid and abscisic acid analogs on the induction of freezing tolerance of winter rye (Secale cereale L.) seedlings. Plant Growth Regulat. 25:35-45.

Coombe, B.G. 1995. Adoption of a system for identifying grapevine growth stages. Aust. J. Grape Wine Res. 1:100110.

Dallaire, S., M. Houde, Y. Gagne, H.S. Saini, S. Boileau, N. Chevrier, and F. Sarhan. 1994. ABA and low-temperature induce freezing tolerance via distinct regulatory pathways in wheat. Plant Cell Physiol. 35:1-9.

Dami, I.E. and B.A. Beam. 2004. Response of grapevines to soybean oil application. Amer. J. Enol. Viticult. 55:269275.
Dami, I.E. and D. Lewis. 2014. 2014 Grape winter damage survey report. Ohio State Univ. Dept. Hort. Crop Sci. Ser. Bul. 816.

Dami, I.E., D. Kinney, and S. Li. 2014. Polar vortex and its impact on grapes. Ohio Grape-Wine Electronic Nwsl. Ohio State Univ. 10 Jan. 2014. (Special Issue):2-6.

Dami, I.E., S. Ennahli, and Y. Zhang. 2012. Assessment of winter injury in grape cultivars and pruning strategies following a freezing stress event. Amer. J. Enol. Viticult. 63:106-111.

Guak, S. and L.H. Fuchigami. 2001. Effects of applied ABA on growth cessation, bud dormancy, cold acclimation, leaf senescence and $\mathrm{N}$ mobilization in apple nursery plants. J. Hort. Sci. Biotechnol. 76:459-464.

Hellman, E., S. Shelby, and C. Lowery. 2006. Exogenously applied abscisic acid did not consistently delay bud break of deacclimating grapevine. J. Amer. Pomol. Soc. 60:178-186.

Kumar, S., G. Kaur, and H. Nayyar. 2008. Exogenous application of abscisic acid improves cold tolerance in chickpea (Cicer arietinum L.). J. Agron. Crop Sci. 194:449-456.

Lee, I.C., S.W. Hong, S.S. Whang, P.O. Lim, H.G. Nam, and J.C. Koo. 2011. Age-dependent action of an ABA-inducible receptor kinase, $\mathrm{RPKl}$, as a positive regulator of senescence in Arabidopsis leaves. Plant Cell Physiol. 52:651-662.

Li, C., O. Junttila, P. Heino, and T.E. Palva. 2003. Different responses of northern and southern ecotypes of Betula pendula to exogenous ABA application. Tree Physiol. 23:481-487.

Lurie, S., R. Ovadia, A. Nissim-Levi, M. Oren-Shamir, T. Kaplunov, Y. Zutahy, W. Hovav, and A. Lichter. 2009. Abscisic acid improves colour development in 'Crimson Seedless' grapes in the vineyard and on detached berries. J. Hort. Sci. Biotechnol. 84:639-644.

Mantyla, E., V. Lang, and E.T. Palva. 1995. Role of abscisic-acid in droughtinduced freezing tolerance, cold-acclimation, and accumulation of LT178 and RAB18 proteins in Arabidopsis thaliana. Plant Physiol. 107:141-148.

Mills, L.J., J.C. Ferguson, and M. Keller. 2006. Cold-hardiness evaluation of grapevine buds and cane tissues. Amer. J. Enol. Viticult. 57:194-200.

MKF Research. 2007. The impact of wine, grapes, and grape production on the American economy: Family businesses building value. MKF Research, Helena, CA.

Mora-Herrera, M.E. and H.A. LopezDelgado. 2007. Freezing tolerance and antioxidant activity in potato microplants induced by abscisic acid treatment. Amer. J. Potato Res. 84:467-475.

Peppi, M.C., M.W. Fidelibus, and N.K. Dokoozlian. 2007. Application timing and concentration of abscisic acid affect the quality of 'Redglobe' grapes. J. Hort. Sci. Biotechnol. 82:304-310.

Poling, E.B. 2008. Spring cold injury to winegrapes and protection strategies and methods. HortScience 43:1652-1662.

Ravaz, L. 1903. Sur la brunissure de la vigne. Les Comptes Rendus de l'Académie des Sciences 136:1276-1278.

U.S. Department of the Interior. 2013. AgriMet Cooperative Agricultural Weather Network. 27 May 2014. <http://www.usbr.gov/pn/agrimet/ webarcread.html>.

Weather Innovations. 2013. Niagara Peninsula. 24 July 2014. <http://www.vineand treefruitinnovations.com/data.cfm? $\mathrm{loc}=\mathrm{NG}>$.

Wolf, T.K. and R.M. Pool. 1987. Factors affecting exotherm detection in the differential thermal-analysis of grapevine dormant buds. J. Amer. Soc. Hort. Sci. 112:520-525.

Zabadal, T., I. Dami, M. Goffinet, T. Martinson, and M. Chien. 2007. Winter injury to grapevine and methods of protection. Michigan State Univ. Ext., East Lansing.

Zhang, Y. and I. Dami. 2012a. Foliar application of abscisic acid increases freezing tolerance of field-grown Vitis vinifera 'Cabernet franc' grapevines. Amer. J. Enol. Viticult. 63:377-384.

Zhang, Y. and I. Dami. 2012b. Improving freezing tolerance of 'Chambourcin'grapevines with exogenous abscisic acid. HortScience 47:1750-1757.

Zhang, Y., T. Mechlin, and I. Dami. 2011. Foliar application of abscisic acid induces dormancy responses in greenhouse-grown grapevines. HortScience $46: 1271-1277$. 